DOE/RW/00134-T T28

Rero

JuL 25903

031
TRW Environmental Safety Systems Inc.

\title{
Diet of Desert Tortoises at Yucca Mountain, Nevada, and Implications for Habitat Reclamation
}

\section{Civilian Radioactive Waste Management System}

Management \& Operating Contractor

B\&W Federal Services Duke Engineering \& Services, Inc. E.R. Johnson Associates, Inc. Fluor Daniel, Inc.

Framatome Cogema Fuels Integrated Resources Group INTERA, Inc.

Prepared by:

TRW Environmental Safety Systems Inc.
JK Research Associates, Inc.

Kiewit/Parsons Brinkerhoff Lawrence Berkeley Laboratory Lawrence Livermore National Laboratory Logicon RDA Los Alamos National Laboratory Morrison-Knudsen Corporation
SAIC

Sandia National Laboratories

TRW Environmental Safety Systems inc.

Woodward-Clyde Federal Services

Winston \& Strawn

Cooperating Federal Agency:

U.S. Geological Survey
Prepared for:

U.S. Department of Energy

Office of Civilian Radioactive Waste

Management

1000 Independence Avenue, S.W.

Washington, D.C. 20565 
Civilian Radioactive Waste Management System Management and Operating Contractor

Diet of Desert Tortoises at Yucca Mountain, Nevada, and Implications for Habitat Reclamation

(SCPB: N/A)

Document No. B00000000-01717-5705-00028

December 1995

Prepared for:

U.S. Department of Energy

Office of Civilian Radioactive Waste Management

101 Convention Center Drive

Las Vegas, NV 89109

Prepared by:

Danny L. Rakestraw, Eric A. Holt, and Kurt R. Rautenstrauch

of

TRW Environmental Safety Systems Inc.

101 Convention Center Drive

Las Vegas, Nevada 89108

Under Contract Number

DE-ACO1-91RW00134 


\section{Civilian Radioactive Waste Management System Management and Operating Contractor}

\section{Diet of Desert Tortoises at Yucca Mountain, Nevada, and Implications for Habitat Reclamation}

\section{December 1995}

\section{Prepared by:}

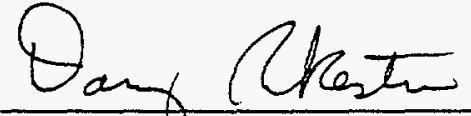

Danny L. Rakestraw; SAIC Inc.

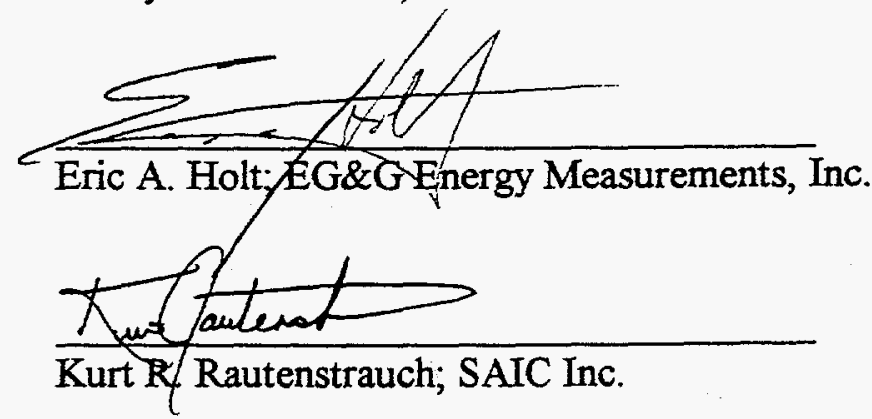

Date:

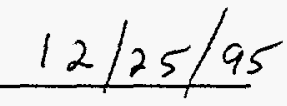

Date:

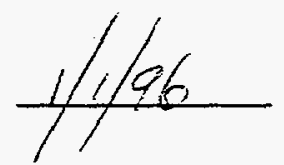

Date:

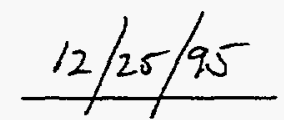

\section{DISCLAIMER}

This report was prepared as an account of work sponsored by an agency of the United States Government. Neither the United States Government nor any agency thereof, nor any of their employees, makes any warranty, express or implied, or assumes any legal liability or responsibility for the accuracy, completeness, or usefulness of any information, apparatus, product, or process disclosed, or represents that its use would not infringe privately owned rights. Reference herein to any specific commercial product, process, or service by trade name, trademark, manufacturer, or otherwise does not necessarily constitute or imply its endorsement, recommendation, or favoring by the United States Government or any agency thereof. The views and opinions of authors expressed herein do not necessarily state or reflect those of the United States Government or any agency thereof. 


\section{ACKNOWLEDGMENTS}

The following people collected data for this study while working for the EG\&G Energy Measurements, Environmental Sciences Department: D. Allen, A. Ambos, M. Annear, G. Brown, C. Callison, M. Cox, L. Delahunty, R. Delahunty, R. Devisser, M. Fariss, J. Fontaine, A. Gabbert, R. Goodwin, P. Greger, A. Hughes, R. Hunt, M. Janis, W. Kohn, S. Kozusko, S. Leskie, L. Lewis, T. Lindemann, J. Medrano, J. Mueller, D. Pitts, B. Rea, M. Romanowski, M. Saethre, S. Schultz, G. Sharp, K. Sharp, C. Sowell, D. Steen, T. Sue, T. Walrath, and K. Zander.

M. Cox and J. Mueller helped design and implement this study. G. Brown assisted with data management and compiled the weather data included in this report. G. Lyon assisted with plant identification. T. Doerr, R. Green, T. O'Farrell, and K. Ostler provided administrative support.

J. Angerer, R. Green, and P. Lederle reviewed and improved the draft report. 


\begin{abstract}
The diet of desert tortoises at Yucca Mountain was assessed during 1992 to 1995 using a combination of feeding observations and scat analysis. Feeding observation data (1993 through 1995 ) showed that tortoises fed on a wide variety of items. The most frequently eaten items were forbs and annual grasses. These two forage groups comprised more than $90 \%$ of all bites taken. Analysis of scat (1992 and 1993) also showed that grasses and forbs were the most common groups, making up more than $80 \%$ of the composition of scat. Yearly differences between proportions of species in the diet were observed and were most likely attributable to differences in plant productivity, which is linked to rainfall patterns. Non-native species were an important component of the diet in all years, accounting for 13 to $50 \%$ of all bites observed and 6 to $24 \%$ of scat contents. A list of all items encountered in the diet is provided. To facilitate reclamation of desert tortoise habitat disturbed by the Yucca Mountain Site Characterization Project, native forage species that should be included in reclamation seed mixes, when feasible, were identified. Although shrubs make up only a small proportion of the diet, they should also be included in reclamation efforts because they provide habitat structure, tortoise cover sites, and microhabitats amenable to seed germination and seedling establishment. In addition, non-native species should not be planted on reclaimed sites and, if necessary, sites should be recontoured and soil compaction reduced prior to planting.
\end{abstract}




\section{CONTENTS}

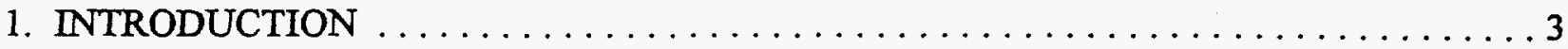

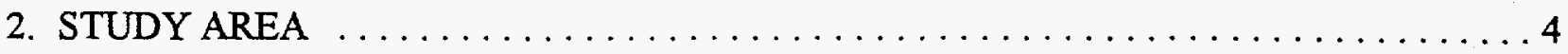

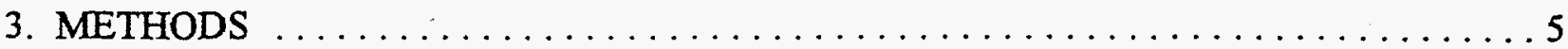

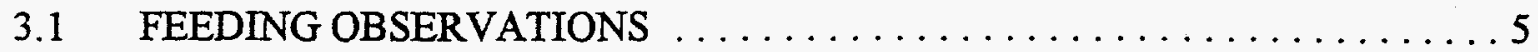

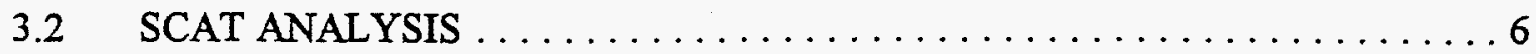

3.3 COMPARISONS AMONG LIFE FORMS $\ldots \ldots \ldots \ldots \ldots \ldots \ldots \ldots$

3.4 PREVALENCE OF EXOTIC SPECIES $\ldots \ldots \ldots \ldots \ldots \ldots \ldots \ldots \ldots$

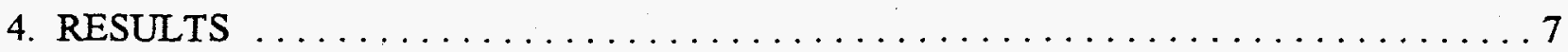

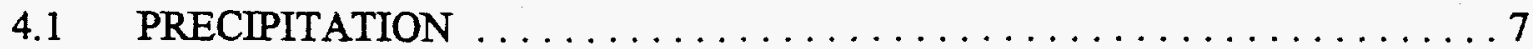

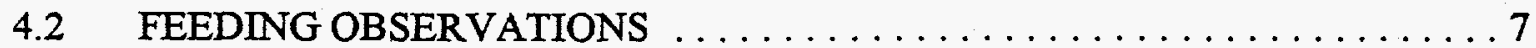

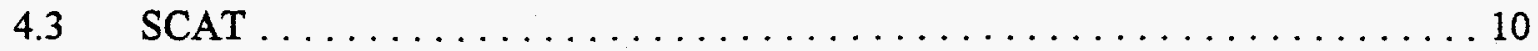

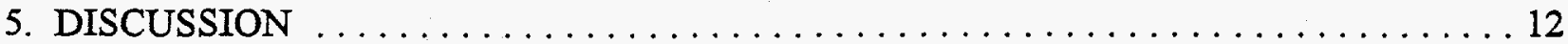

5.1 DIET OF DESERT TORTOISES AT YUCCA MOUNTAIN $\ldots \ldots \ldots \ldots 12$

5.2 IMPLICATIONS FOR HABITAT RECLAMATION $\ldots \ldots \ldots \ldots \ldots \ldots$

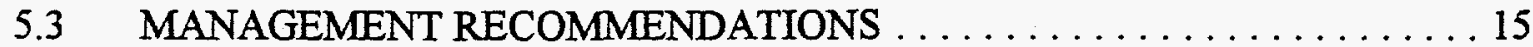

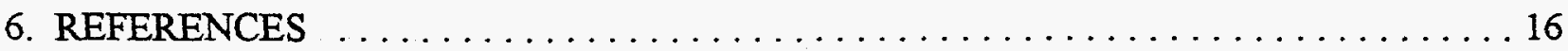




\section{TABLES}

1 Annual rank of percent composition, percent composition (\% Comp), and percent frequency of occurrence (\% Freq) of the five forage species having the highest percent composition in feeding observations of desert tortoises at Yucca Mountain, Nevada, during 1993, 1994, and $1995 \ldots \ldots \ldots \ldots \ldots \ldots \ldots \ldots \ldots$

2 Percent composition of forage-species life forms in the diet of desert tortoises at Yucca Mountain, Nevada, during 1993, 1994, and 1995, as calculated from feeding

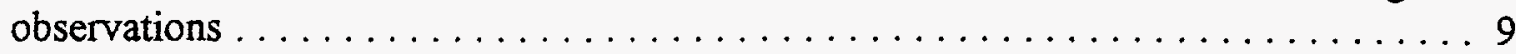

3 Annual rank of percent composition, percent composition (\% Comp), and percent frequency of occurrence (\% Freq) of the five forage species having the highest percent composition in desert tortoise scat collected at Yucca Mountain, Nevada, during 1992 and 1993.

4 Percent composition of forage-species life forms in desert tortoise scat collected at Yucca Mountain, Nevada, during 1992 and 1993.

\section{APPENDICES}

A Percent composition and percent frequency of occurrence of forage species identified during feeding observations of desert tortoises at Yucca Mountain, Nevada, during 1993, 1994, and 1995

B Percent composition and percent frequency of occurrence of forage items in desert tortoise scat collected at Yucca Mountain, Nevada, during 1992 and 1993 


\section{INTRODUCTION}

As directed by the Nuclear Waste Policy Act of 1982 (42 U.S. Code 10101 et seq.), the U.S. Department of Energy (DOE) began studies in 1982 to determine if Yucca Mountain, Nevada, is a suitable site for long-term storage of high-level nuclear waste. Section 113(a) of that Act requires DOE to conduct activities in a manner that minimizes significant adverse environmental impacts to the maximum extent practicable. One of the most obvious environmental impacts of the Yucca Mountain Site Characterization Project will be the disturbance of vegetation and soil during the construction of facilities, excavation of trenches, and creation of drill pads (DOE, 1988). About 370 ha were dusturbed during initial site investigations at Yucca Mountain between 1982 and 1991 (DOE, 1989b), about 120 ha have been disturbed as part of site characterization since 1991 (Hughes et al., in prep.), and 50 additional ha may be disturbed before site characterization is completed.

DOE has developed a reclamation program to minimize these environmental impacts on disturbed lands. The objective of this program is to "return land disturbed by site characterization activities to a stable ecological state with a form and productivity similar to the predisturbance state" (DOE, $1989 b$ ). In addition to meeting the requirement set forth in the Nuclear Waste Policy Act, the reclamation program fulfills specific requirements for land restoration established in the Federal Land Management Policy Act of 1976 (43 USC 1701) and DOE Order 5440.1 implementing the National Environmental Policy Act (DOE, 1989b).

Because of the emphasis DOE has placed on land reclamation to mitigate environmental impacts, DOE proposed implementing reclamation techniques beneficial to the desert tortoise (Gopherus agassizii), a species protected under the Endangered Species Act, to minimize and mitigate impacts on that species (DOE, 1989a). Based on this proposal, the U.S. Fish and Wildlife Service included the following stipulation in the list of actions DOE must implement to ensure compliance with the Endangered Species Act: "Efforts will be made to grow forage palatable to tortoises, and to develop other physical habitat features important to tortoises in these reclaimed areas" (U.S. Fish and Wildlife Service, 1990).

To fulfill this requirement, DOE must know what forage species desert tortoises eat at Yucca Mountain. The diet of desert tortoises has been studied throughout much of the species' range in the United States (National Ecological Research Center, 1990). Desert tortoises are herbivores and feed primarily on annual forbs and grasses and include a wide variety of other herbaceous materials in their diet (Woodbury and Hardy, 1948; Burge and Bradley, 1976; Nagy and Medica, 1986; Jennings, 1993; Esque, 1994; Henen, 1994). Many studies have shown that the diet of desert tortoises varies among locations (Hansen et al., 1976; Snider, 1992; Esque, 1994), as well as within years (Burge and Bradley, 1976; Nagy and Medica, 1986; Jennings, 1993) and between years (Esque, 1994; Henen, 1994). Esque (1994) found that the species composition in the diet of desert tortoises differed between two sites about $20 \mathrm{~km}$ apart in southwestern Utah, as well as among years. He stated that the differences shown between sites and among years were primarily the result of differences in forage availability. Similar results were reported by Hansen et al. (1976) for study sites in northern Arizona and southwestern Utah.

Two studies of the diet of desert tortoises have been conducted near Yucca Mountain. Desert tortoises in Rock Valley, Nevada, approximately $25 \mathrm{~km}$ southeast of Yucca Mountain, ate three 
species of annuals (Camissonia munzii, Langloisia setosissima, and Bromus rubens) and one perennial grass (Oryzopsis hymenoides) (Nagy and Medica, 1986). Tortoises near Arden, Nevada, approximately $130 \mathrm{~km}$ southeast of Yucca Mountain, fed primarily on the annual forbs Plantago insularis and Euphorbia albomarginata, the annual grass Festuca octoflora, and the perennial forb Sphaeralcea ambigua (Burge and Bradley, 1976). Despite the proximity of these areas to Yucca Mountain, some of the species listed as major dietary components in these studies are rare at Yucca Mountain (Angerer et al., 1994).

Because of the spatial and temporal variability of desert tortoise diets, and the limited information available on diet for the general vicinity of Yucca Mountain, it was important to determine the diet characteristics of tortoises at Yucca Mountain to maximize the benefit of habitat reclamation efforts. To fulfill this need, a study with the following objectives was developed and implemented

1. Identify forage species commonly eaten by desert tortoises at Yucca Mountain.

2. Identify forage species that can be used during habitat reclamation at Yucca Mountain to improve the quality of disturbed sites for desert tortoises.

This report summarizes the findings of that study, discusses the feasibility of incorporating forage species in habitat reclamation, and provides a set of recommendations for habitat reclamation.

\section{STUDY AREA}

Yucca Mountain is on the southwestern edge of the U.S. Department of Energy's Nevada Test Site in Nye County, Nevada, approximately $26 \mathrm{~km}$ north of the town of Amargosa Valley (formerly known as Lathrop Wells). The study area lies on the northern edge of the Mojave Desert in a region characterized by linear mountain ranges and broad valleys. The portion of Yucca Mountain being evaluated by DOE as a potential geologic repository is a volcanic ridge oriented north to south, with a maximum elevation of about $1,500 \mathrm{~m}$. The tortoises included in this study occupy the eastern slope of Yucca Mountain from its crest down to Fortymile Canyon (elevation 1,100 m) and into the bajadas of the Calico Hills, approximately $8.5 \mathrm{~km}$ east of Yucca Mountain.

This area includes two major floristic zones, a Mojave Desert zone and a transition zone between the Mojave and Great Basin deserts. Three vegetation associations commonly found in these zones cover most of the study area (O'Farrell and Collins, 1984; DOE Yucca Mountain Site Characterization Project Office [DOE/YMP], unpubl. data). An association dominated by Larrea tridentata, Ambrosia dumosa, Grayia spinosa, and Ephedra nevadensis is found in the Mojave Desert zone on bajadas below about $1,300 \mathrm{~m}$. Ephedra nevadensis, Grayia spinosa, and Lycium andersonii dominate one transition zone vegetation association on bajadas above $1,300 \mathrm{~m}$ and on the upper slopes of Yucca Mountain. Another transition zone association is dominated by Coleogyne ramosissima and is found on relatively level ridges of the upper bajadas, between about 1,160 and $1,500 \mathrm{~m}$.

The climate of the Yucca Mountain area is typical of the eastern Mojave Desert, with limited and erratic precipitation, low relative humidity, and large daily temperature fluctuations. Average annual precipitation between 1960 and 1995 at weather station $4 \mathrm{JA}$, approximately $13 \mathrm{~km}$ southeast of the 
study area, was $13.9 \mathrm{~cm}$ (DOE Nevada Operations Office, unpubl. data). During this 35-year period, $43 \%$ of the precipitation occurred during the three months of January $(\bar{x}=1.9 \mathrm{~cm})$, February $(\bar{x}=$ $2.1 \mathrm{~cm})$, and March $(\bar{x}=2.1 \mathrm{~cm})$. Only $12 \%$ of the precipitation occurred in April $(\bar{x}=0.6 \mathrm{~cm})$, May $(\bar{x}=0.8 \mathrm{~cm})$, and June $(\bar{x}=0.3 \mathrm{~cm})$. Daily temperatures have been recorded at Yucca Mountain since 1986 (DOE/YMP, unpubl. data). The average daily minimum and maximum temperatures during December, the coldest month at Yucca Mountain, were $2^{\circ} \mathrm{C}$ and $10^{\circ} \mathrm{C}$, respectively. The average daily minimum and maximum temperatures for the hottest month, July, were $22^{\circ} \mathrm{C}$ and $34^{\circ} \mathrm{C}$, respectively.

\section{METHODS}

This study was part of a larger program conducted to evaluate and mitigate the impacts of Yucca Mountain Site Characterization activities on desert tortoises (Rautenstrauch et al., 1991). For that program about 100 desert tortoises were fitted with radio transmitters and monitored from 1991 to 1995. These tortoises were located and observed one to seven times each week during the active season (i.e., March through November) to fulfill the objectives of the many studies being conducted. Data for this diet study were collected opportunistically during routine monitoring of these tortoises.

Two techniques were used to study the diet of desert tortoises: observations of tortoises feeding and microhistological analysis of scat. Data from these techniques were used to identify which species or groups of species were eaten by tortoises at Yucca Mountain, the relative abundance of the vegetative life forms found in the diet, and the prevalence of non-native species in the diet. Annual precipitation data collected on the study site by the Yucca Mountain Project were used to help explain yearly differences in the diet of desert tortoises.

\subsection{FEEDING OBSERVATIONS}

When a radiomarked tortoise was seen feeding during 1993, 1994, and 1995, the observer followed the tortoise at a distance which allowed identification of forage items with binoculars, without disturbing the tortoise. Foraging was observed for about 15 minutes or until the tortoise stopped feeding, and the observer recorded the number of bites taken from each plant species eaten. Because the tortoise may have been feeding prior to the observer's arrival and after the 15-minute period, these data do not represent complete feeding bouts, which have been shown to last from 1 to 43 minutes (Burge and Bradley, 1976; Esque, 1994). Plants were identified to the lowest taxonomic level possible. If a plant could not be identified, it was listed as unknown forage.

From these data annual percent composition and frequency of occurrence were calculated for each forage item. Percent composition indicates the relative amount of each item in the diet. This value was calculated by dividing the total number of bites counted for a forage item during all feeding observations in a year by the total number of bites counted for that year and multiplying by 100 . With relatively small sample sizes, this calculation may overestimate the relative importance of an item in the diet if that item was seen in only a few feeding bouts but a large number of bites were taken. To compensate for this possibility, the annual percent frequency of occurrence for each forage item was calculated by dividing the number of feeding observations in which the species was eaten that year by the total number of feeding observations for that year and multiplying by 100 . This value indicates how often a species was eaten by tortoises. 


\section{$3.2 \quad$ SCAT ANALYSIS}

In 1992 and 1993, fresh scat was collected, placed in a paper bag with one tablespoon of table salt, and stored at room temperature. Scat was known to be fresh if it was seen being deposited by a tortoise, was found in a box used to transport a tortoise, was found along the thread trail of a female tortoise being monitored to find nests, or when it was not associated with a monitored tortoise but was still moist.

The mean percent relative density of fragments of each forage item was determined by AAFAB Composition Analysis Laboratory in Fort Collins, Colorado, using the procedures described in Sparks and Malechek (1968). Mean percent relative density is representative of and equal to relative percent composition (Sparks and Malechek, 1968). For each scat, three microscope slides were prepared and 20 fields on each slide were examined at 125× magnification. A list of plant species found at Yucca Mountain and specimens of local species not present in the Laboratory's reference collection were submitted to the Laboratory to aid in identification of vegetative fragments.

Scat contents were identified to the lowest taxonomic level possible. However, despite using an extensive reference collection, it was difficult to classify some fragments to species. In many cases, a fragment of vegetation could only be classified to genus or family. When fragments could not be assigned confidently to a family or lower taxonomic level, they were classified as unknown.

As with feeding observations, two values were calculated from the mean percent relative density (i.e., percent composition) for each forage item. First, to obtain an index of the relative amount of each forage item in the diet, percent composition for each item was calculated by summing the mean percent relative density for an item in all scat, dividing by the total number of scat analyzed, and multiplying by 100 . Because the percent composition is an average of percentages, the sum of percent compositions for all forage items will not necessarily total $100 \%$. To obtain an index of how often each forage item was eaten, the frequency of occurrence was calculated for scat by counting the number of scat in which the forage item was found, dividing by the number of scat analyzed, and multiplying by 100 .

\subsection{COMPARISONS AMONG LIFE FORMS}

For feeding observations and the scat analysis, each forage item was classified using Beatley (1976) into one of seven categories: annual forb, perennial forb, annual or perennial forb, annual grass, perennial grass, shrub, or other. The category "annual or perennial forb" represents forage groups identified to a family or genus that include both annual and perennial species in the local community. For example, the forage group Astragalus spp. was classified as "annual or perennial forb" because annual and perennial species of Astragalus are found at Yucca Mountain. If the local species comprising a forage group classified only to family or genus fit into one of the five detailed categories, the group was classified accordingly. For example, Lupinus spp. was classified as an annual forb because all lupines found at Yucca Mountain are annual forbs. Forage groups that included both forbs and shrubs (e.g., Composites) were classified as "other" for this analysis. 
Percent composition was calculated for each category. For feeding observation data, percent composition was calculated as the total number of bites taken per life form per year, divided by the total bites for the year, and multiplied by 100 . For the scat analysis data, annual percent composition was calculated by summing the percent composition of all forage items within each classification. Again, because the percent composition is an average of percentages, the sum of percent composition for all categories may not equal $100 \%$.

\subsection{PREVALENCE OF EXOTIC SPECIES}

Beatley (1976) was used to classify forage items as native or non-native (i.e., exotic) to the region. Percent composition and percent frequency of occurrence of native and exotic species were calculated for feeding observations and scat data using the calculations described in the previous section.

\section{RESULTS}

\subsection{PRECIPITATION}

Annual precipitation at Yucca Mountain during $1992(27.0 \mathrm{~cm}), 1993(26.6 \mathrm{~cm})$, and $1995(26.1 \mathrm{~cm})$ was almost twice the long-term average $(13.9 \mathrm{~cm})$ for this area. These years were three of the five wettest years from 1960 through 1995. Rainfall during $1994(11.7 \mathrm{~cm})$ was slightly less than the long-term average.

\subsection{FEEDING OBSERVATIONS}

\subsubsection{3}

In 1993, 6,298 bites were counted during 100 observations of 55 feeding tortoises and 30 forage items were identified (Appendix A1). Lotus humistratus, a native annual forb, comprised $47 \%$ of the diet (percent composition) and was eaten during 52\% of the foraging bouts (frequency of occurrence). Bromus rubens, an exotic annual grass, accounted for only $13 \%$ of the diet but was eaten during $40 \%$ of the bouts. The five forage items eaten in the greatest quantity comprised $78 \%$ of the bites counted (Table 1). Four of these also were eaten most frequently. The other, Mentzelia obscura, was only observed being eaten once, when a large quantity was consumed in a short period. The importance of Mentzelia obscura in the 1993 diet therefore is probably overestimated by the calculation of percent composition. Most $(n=21)$ of the forage items each made up $\leq 1 \%$ of the diet and were eaten infrequently (i.e., $<5 \%$ ).

Twenty-three fort taxa comprised $84 \%$ of the bites counted during 1993 and four grasses comprised $15 \%$ (Table 2). A tortoise was observed eating a shrub only once in 1993. Tortoises were observed eating two non-native species (Bromus rubens and Erodium cicutarium) in 1993; these species comprised $16 \%$ of the diet and were eaten during $41 \%$ of the feeding bouts. 
Table 1. Annual rank of percent composition, percent composition (\% Comp), and percent frequency of occurrence (\% Freq) of the five forage species having the highest percent composition in feeding observations of desert tortoises at Yucca Mountain, Nevada, during 1993, 1994, and 1995.

\begin{tabular}{|c|c|c|c|c|c|c|c|c|c|}
\hline \multirow[b]{2}{*}{ Species } & \multicolumn{3}{|c|}{$\begin{array}{c}1993 \\
(n=6,298 \text { bites })\end{array}$} & \multicolumn{3}{|c|}{$\begin{array}{c}1994 \\
(n=4,324 \text { bites })\end{array}$} & \multicolumn{3}{|c|}{$\begin{array}{c}1995 \\
(n=3,374 \text { bites })\end{array}$} \\
\hline & Rank & $\%$ Comp & $\%$ Freq & Rank & $\%$ Comp & $\%$ Freq & Rank & $\%$ Comp & $\%$ Freq \\
\hline $\begin{array}{l}\text { Lotus } \\
\text { humistratus }\end{array}$ & 1 & 46.8 & 52.0 & 2 & 17.0 & 23.6 & 1 & 34.8 & 48.3 \\
\hline Bromus rubens & 2 & 12.8 & 40.0 & 1 & 46.1 & 67.4 & 5 & 4.3 & 24.1 \\
\hline $\begin{array}{l}\text { Amsinckia } \\
\text { tessellata }\end{array}$ & 3 & 6.6 & 14.0 & 4 & 4.5 & 13.5 & 14 & 0.9 & 5.2 \\
\hline $\begin{array}{l}\text { Mentzelia } \\
\text { obscura }\end{array}$ & 4 & 6.2 & 1.0 & & & & & & \\
\hline $\begin{array}{l}\text { Sphaeralcea } \\
\text { ambigua }\end{array}$ & 5 & 5.7 & 11.0 & 3 & 11.8 & 7.9 & 2 & 17.9 & 12.1 \\
\hline $\begin{array}{l}\text { Stephanomeria } \\
\text { spp. }^{1}\end{array}$ & 6 & 5.7 & 1.0 & 5 & 4.3 & 2.2 & 17 & 0.2 & 1.7 \\
\hline $\begin{array}{l}\text { Erodium } \\
\quad \text { cicutarium }\end{array}$ & 7 & 2.9 & 3.0 & 7 & 3.8 & 10.1 & 3 & 8.8 & 3.4 \\
\hline Astragalus spp. ${ }^{2}$ & & & & 15 & 0.3 & 2.2 & 3 & 8.8 & 8.6 \\
\hline
\end{tabular}

${ }^{1}$ Recorded as Stephanomeria spp. in 1993, S. parryi in 1994, and S. parryi and S. pauciflora in 1995.

${ }^{2}$ Recorded as Astragalus calycosus and A. layneae in 1994, and Astragalus spp. in 1995.

\subsubsection{4}

In 1994, 4,324 bites were counted during 89 observations of 61 tortoises and 18 forage items were identified (Appendix A2). Bromus rubens accounted for $46 \%$ of the diet composition and was eaten during $67 \%$ of the foraging bouts. The five forage items eaten in greatest quantity comprised $84 \%$ of the bites counted (Table 1). Eight forage items each made up $\leq 1 \%$ of the diet.

In contrast to 1993, grasses were eaten more than forbs in 1994 (Table 2). Four grass taxa comprised $51 \%$ of the diet and ten species or genera of forbs accounted for $47 \%$. One percent of the bites observed were of four species of shrubs. Three non-native species (Bromus rubens, Bromus tectorum, and Erodium cicutarium) made up 50\% of the diet and were eaten during $73 \%$ of the bouts during 1994. 
Table 2. Percent composition of forage-species life forms in the diet of desert tortoises at Yucca Mountain, Nevada, during 1993, 1994, and 1995, as calculated from feeding observations.

\begin{tabular}{lccc}
\hline Life Form & 1993 & 1994 & 1995 \\
\hline Forbs & & & \\
Annual & 69.9 & 26.6 & 61.2 \\
Perennial & 14.4 & 20.1 & 18.9 \\
Annual or Perennial & & 0.2 & 8.8 \\
Grasses & & & \\
Annual & & 46.5 & 4.3 \\
Perennial & 12.9 & 4.9 & 0.1 \\
Shrubs & 1.9 & 1.0 & 1.1 \\
Other & $<0.1$ & $0.6^{3}$ & $5.7^{4}$ \\
\hline
\end{tabular}

${ }^{1}$ Includes plants of the genus Astragalus that were not identified to species.

${ }^{2}$ Lichen $(<0.1 \%)$, lagomorph scat $(0.1 \%)$, and unidentified plant species $(0.9 \%)$.

${ }^{3}$ Unidentified plant species.

${ }^{4}$ Cactus (1.0\%) and unidentified plant species (4.7\%).

\subsubsection{5}

In 1995, 3,374 bites were counted during 58 observations of 45 tortoises and 22 forage items were identified (Appendix A3). As in 1993, Lotus humistratus was eaten the most, comprising $35 \%$ of the diet, and was the most frequently eaten species, occurring in $48 \%$ of the feeding bouts (Table 1 ). Sphaeralcea ambigua, a native perennial forb, also comprised a relatively large part of the diet (18\%). Bromus rubens accounted for only $4 \%$ of the diet but was eaten during $24 \%$ of feeding bouts in 1995. The five forage items eaten in greatest quantity comprised $75 \%$ of the bites counted (Table 1). Twelve forage items comprised $\leq 1 \%$ of the diet.

In 1995, eighteen forb taxa comprised at least $89 \%$ of the diet (Table 2). Two grasses accounted for only $4 \%$ of the diet. Tortoises were observed eating a cactus and a shrub once each. Two non-native species (Bromus rubens and Erodium cicutarium) comprised 13\% of the diet and were eaten during $28 \%$ of the bouts. 


\subsection{SCAT ANALYSIS}

\subsubsection{2}

In 1992, 88 scat were collected and analyzed. Forty forage items were identified, including hair, arthropods, bone, fungus, and 36 taxa of vegetation (Appendix B1). Sixteen forage items were found in $>10 \%$ of the scat (frequency of occurrence); however, only three comprised $>10 \%$ of the scat contents (percent composition). Sphaeralcea ambigua had the highest percent composition (26\%) and was found in $75 \%$ of the scat. Bromus rubens and the forage group Lotus spp.-Lupinus spp. also comprised relatively large proportions of the scat. Schismus arabicus, an exotic annual grass, had the fourth highest percent composition (Table 3). However, this species is uncommon at Yucca Mountain and tortoises were not observed eating it during 1993 to 1995. Schismus arabicus may have been confused with other species, possibly annual grasses, during analysis of scat. The forage item with the fifth highest percent composition was plants from the Boraginaceae family. Amsinckia tessellata was the only member of this family tortoises were seen eating often during 1993 to 1995; species of the genera Cryptantha and Pectocarya were eaten only infrequently (Appendix A).

Forbs and grasses comprised 50 and $27 \%$, respectively, of the scat content in 1992 (Table 4). Although 10 species or genera of grasses were identified (Appendix B1), only two annual grasses (Bromus rubens and Schismus arabicus) and 2 perennial grasses (Sporobolus cryptandrus and Hilaria jomesii) had a composition of $>1 \%$. Eight species or genera of shrubs comprised $3 \%$ of the scat composition; none of these shrubs individually had a percent composition $>1 \%$.

One non-native forb (Erodium cicutarium) and two non-native grasses (Bromus rubens and Schismus arabicus) were found in scat collected in 1992 . These species comprised $24 \%$ of the scat composition and were found in $89 \%$ of the scat.

Table 3. Annual rank of percent composition, percent composition ( $\%$ Comp), and percent frequency of occurrence ( $\%$ Freq) of the five forage species having the highest percent composition in desert tortoise scat collected at Yucca Mountain, Nevada, during 1992 and 1993.

\begin{tabular}{|c|c|c|c|c|c|c|}
\hline \multirow[b]{2}{*}{ Species } & \multicolumn{3}{|c|}{$1992(n=88$ scat $)$} & \multicolumn{3}{|c|}{$1993(n=88$ scat $)$} \\
\hline & Rank & $\%$ Comp & $\%$ Freq & Rank & $\%$ Comp & $\%$ Freq \\
\hline Sphaeralcea ambigua & 1 & 25.8 & 75.0 & 2 & 18.5 & 58.0 \\
\hline Lotus spp.-Lupinus spp. & 2 & 15.4 & 51.1 & 1 & 31.6 & 58.0 \\
\hline Bromus rubens & 3 & 14.5 & 78.4 & 5 & 2.0 & 42.1 \\
\hline Schismus arabicus & 4 & 7.0 & 35.2 & 20 & $<0.1$ & 6.8 \\
\hline Boraginaceae & 5 & 3.1 & 31.8 & 3 & 12.7 & 75.0 \\
\hline Erodium cicutarium & 8 & 2.0 & 28.4 & 4 & 3.8 & 31.8 \\
\hline
\end{tabular}


Table 4. Percent composition of forage-species life forms in desert tortoise scat collected at Yucca Mountain, Nevada, during 1992 and 1993.

\begin{tabular}{lcc}
\hline Life Form & 1992 & 1993 \\
\hline Forbs & & \\
Annual & 19.1 & 35.7 \\
Perennial & 26.1 & 18.5 \\
Annual or Perennial & $4.5^{1}$ & $14.0^{2}$ \\
Grasses & & \\
Annual & 21.5 & 2.1 \\
Perennial & 5.5 & 3.1 \\
Shrubs & 2.9 & 0.5 \\
Qther & $14.4^{3}$ & $19.6^{4}$ \\
\hline
\end{tabular}

${ }^{1}$ Includes plants not classified to species in the forage groups Boraginaceae (3.1\%), Oenothera spp. $(0.8 \%)$, Polemoniaceae $(0.4 \%)$, Cirsium spp. $(0.1 \%)$, and Cryptantha spp. $(\triangleleft 0.1 \%)$.

2 Includes plants not identified to species in the forage groups Boraginaceae (12.7\%), Polemoniaceae (1.3\%), and Oenothera spp. $(<0.1 \%)$.

${ }^{3}$ Includes arthropods (2.7\%), cactus (1.4\%), legumes (0.5\%), composites $(0.3 \%)$, hair (0.3\%), Astragalus spp. ( $\left.\varangle .1 \%\right)$, bone $(\varangle 0.1 \%)$, pollen $(\varangle 0.1 \%)$, fungus $(\varangle 0.1 \%)$, and all unknown vegetation $(8.9 \%)$.

${ }^{4}$ Includes arthropods $(1.1 \%)$, cactus $(1.0 \%)$, legumes $(1.0 \%)$, Brassicaceae $(0.4 \%)$, bone $(\varangle 0.1 \%)$, fungus $(\varangle 0.1 \%)$, and all unknown vegetation (15.9\%).

\subsubsection{3}

In 1993, 143 scat were collected but because of funding constraints, only 88 samples were analyzed to match the sample size from the previous year. The scat selected maximized the number of individual tortoises included in the sample. Thirty-three forage items were identified (Appendix B2). Nine items were found in $>10 \%$ of the scat. Only three forage groups comprised $>4 \%$ of the scat composition: Lotus spp.-Lupinus spp. (32\%), Sphaeralcea ambigua (19\%), and plants in the family Boraginaceae (13\%) (Table 3).

The proportion of forbs in scat collected in 1993 (68\%) was higher than in scat collected in 1992 $(50 \%)$ (Table 4). Conversely, the proportion of grasses $(5 \%)$ and shrubs $(<1 \%)$ in 1993 scat decreased compared to 1992 (27\% grasses and 5\% shrubs). The exotic annuals Erodium cicutorium, Bromus rubens, and Schismus arabicus made up $6 \%$ of the composition, and were found in $65 \%$ of the scat in 1993. 


\section{DISCUSSION}

\subsection{DIET OF DESERT TORTOISES AT YUCCA MOUNTAIN}

During this study, desert tortoises at Yucca Mountain fed almost exclusively on forbs and grasses. Shrubs and cacti comprised $\leq 2 \%$ of bites in all years (Table 2) and $\leq 4 \%$ of the scat content (Table 4). Similar results have been obtained during almost all other studies of the diet of desert tortoises (Burge and Bradley, 1976; Hansen et al., 1976; Nagy and Medica, 1986; Jennings, 1993; Esque, 1994). In contrast, desert tortoises in Ivanpah Valley, California (Turner et al., 1984), and near Goffs, California (Henen, 1994), ate a substantial amount of cacti during droughts when succulent forbs and grasses were not available. Though cacti were not found in the diet of tortoises at Yucca Mountain during the relatively wet years of this study, cacti did occur in a small sample of scat $(n=$ 57) collected in the relative dry years of $1990(20 \%)$ and $1991(4 \%)$ as part of a pilot study (EG\&G, 1994). However, due to small sample sizes and technique differences, these data cannot be compared directly to data collected during this study.

Although tortoises were observed eating 42 forage items during 1993 to 1995 and 45 forage items in all scat collected in 1992 and 1993, tortoises at Yucca Mountain relied heavily on very few of these items. Three species, Lotus humistratus, Bromus rubens, and Sphaeralcea ambigua, accounted for 57 to $75 \%$ of the bites counted each year. Similarly, the three forage items Lotus spp.-Lupinus spp., Bromus rubens, and Sphaeralcea ambigua comprised 52 to $56 \%$ of the scat contents. Other studies have reported similar results; tortoises feed on a wide variety of items, yet a few species made up most of their diet (Burge and Bradley, 1976; Jennings, 1993; Esque, 1994). For example, Esque (1994) observed tortoises eating 13 to 68 forage items per year at two sites in the northeastern Mojave Desert, but in most years $>75 \%$ of the bites were of three species. In contrast, Nagy and Medica (1986) observed tortoises eating only four species at Rock Valley, $25 \mathrm{~km}$ east of Yucca Mountain.

The diet of desert tortoises at Yucca Mountain differed among years. Based on feeding observations during 1993, tortoises fed primarily on forbs (84\%), particularly annual forbs (Table 2). Precipitation during the winter prior to 1993 was high; consequently, plant production was high (DOE/YMP, unpubl. data; see also Beatley, 1974). During 1994, only about half of the diet was comprised of forbs. Grasses, primarily the exotic annual Bromus rubens, comprised the other half of the diet. Precipitation and plant productivity was below average during 1994 (DOE/YMP, unpubl. data). In 1995 , another very wet year, the diet was similar to $1993 ; 87 \%$ was comprised of forbs, and grasses were eaten infrequently. Most of these differences can be accounted for by examining the yearly differences in consumption of the annual forb Lotus humistratus; the annual grass Bromus rubens; and to a lesser extent, the perennial forb Sphaeralcea ambigua (Table 1).

The composition of scat also differed among years. The proportion of forbs increased from 1992 $(50 \%)$ to $1993(68 \%)$ and the proportion of grasses decreased (27\% vs. $5 \%)$. However, precipitation was well above average both years.

To better understand the cause of these yearly differences in diet it would be necessary to measure annual production and availability of key forage species. Only a few other studies have compared diet of desert tortoises among years. In Ivanpah Valley, California, tortoises ate primarily annual forbs, 
annual grasses, and cacti during a year with moderate to low rainfall and production. The following year, which had very little rainfall or production, the tortoises ate cacti and annual grasses during the spring and cacti almost exclusively during the summer (Medica et al., 1982; Tumer et al., 1984). During a relatively wet spring at Goffs, California, the tortoise diet consisted primarily of forbs and grasses. During dry periods the proportion of forbs in the diet decreased and the proportion of grasses and cacti in the diet increased (Henen; 1994). Comparing relatively wet and dry years in the northeastern Mojave Desert, Esque (1994) found similar results.

Non-native species accounted for 13 to $50 \%$ of the bites taken during feeding observations each year and comprised 6 to $24 \%$ of the scat contents collected each year. Most of this variation among years was due to annual differences in consumption of Bromus rubens. The only other non-native plants that accounted for $>1 \%$ of the composition of foraging observations or scat contents were Erodium cicutarium and Schismus arabicus. These or closely-related exotic plants also comprised a large part of the diet of tortoises elsewhere in the Mojave Desert in some years (Hansen et al., 1976; Esque, 1994; Henen, 1994).

\subsection{IMPLICATIONS FOR HABITAT RECLAMATION}

To minimize and mitigate impacts on desert tortoises of the Yucca Mountain Site Characterization Project, DOE (1989a) stated that "efforts will be made to grow forage palatable to tortoises, and to develop other physical habitat features important to tortoises in these reclaimed areas." To support that goal, this study was developed to identify plant species which are eaten by tortoises and can be included in reclamation efforts. However, diet composition is not the only important factor to consider when reclaiming desert tortoise habitat. Issues such as natural revegetation rates of disturbed areas, nutritive quality of forage, feasibility of incorporating diet items into reclamation efforts, germination requirements of forage species, and other habitat requirements of desert tortoises also should be considered when developing reclamation strategies.

Many species commonly eaten by desert tortoises at Yucca Mountain grow on disturbed sites that have not been reclaimed. Amsinckia tessellata, Bromus rubens, Erodium cicutarium, Eriogonum inflatum, Gilia spp., and Stephanomeria pauciflora were found in non-reclaimed disturbed areas (Angerer et al., 1994) and were present in the desert tortoise diet (Appendices A and B). Some of these species comprised a large portion of the diet (e.g., Bromus rubens and Amsinckia tessellata) (Tables 1 and 3 ). Since these species readily invade disturbed areas, incorporating them into reclamation efforts as food sources for tortoises may not be necessary. Additionally, several of the species found on disturbed sites are not native to this region (e.g., Bromus rubens, Erodium cicutarium, and Schismus arabicus). Because of concerns about the impacts of an increase in exotic plants on desert ecosystems (D'Antonio and Vitousek, 1992; U.S. Fish and Wildlife Service, 1994), non-native species should not be included in reclamation efforts.

Many of the annual forbs commonly eaten by tortoises at Yucca Mountain, such as Lotus humistratus, Lupinus spp., and Astragalus spp., are uncommon in disturbed areas (Angerer et al., 1994). These species likely do not colonize disturbed areas because the distribution of these species is patchy in the vegetation community or they produce few seeds that are relatively heavy and require birds, rodents, or water flow for dissemination. Because annual forbs are rich in nutrients when succulent (McArthur et al., 1994), and because they generally are eaten by desert tortoises more than 
other types of forage, it would be beneficial to grow them on reclaimed sites. However, including some of these species in reclamation efforts may not be feasible. Seeds of many annuals are not available from commercial producers and are difficult to harvest at Yucca Mountain because of their small size and lack of abundance during most years. Additionally, it may be necessary to seed these species in more than one year to ensure establishment. However, when possible, native annual forbs commonly eaten by desert tortoises, especially Lotus humistratus, Mentzelia obscura, and local Lupinus spp. and Astragalus spp., should be included in the seed mix during reclamation.

Although annual forbs may be difficult to include during reclamation, perennial forbs are feasible to use and are often eaten by tortoises. For example, $>10 \%$ of the bites counted in two of three years were of the native perennial forb Sphaeralcea ambigua (Table 1). This species has locally-grown, commercially-available seeds and when included in the seed mix for reclaimed sites on Yucca Mountain, has produced densities comparable to or higher than on undisturbed sites (DOE/YMP, unpubl. data). This species, especially its flowers, are high in nitrogen, phosphorus, and other nutrients that may be limiting in desert environments (Morgart et al., 1986; McArthur et al., 1994). Other perennial forbs, such as Eriogonum inflatum, Stephanomeria pauciflora, Calochortus flexuosus, and Euphorbia albomarginata also are eaten by tortoises, are high in some nutrients (Jarchow, 1984; Rautenstrauch et al., 1988; McArthur et al., 1994), and may have commerciallyavailable seed. Though a few of these readily invade disturbed sites (e.g., Eriogonum inflatum and Stephanomeria pauciflora), others should be considered during reclamation.

In general, perennial grasses were eaten only infrequently at Yucca Mountain (Tables 2 and 4). However, Erioneuron pulchellum comprised 4\% of the bites in 1994 and Stipa speciosa, Oryzopsis hymenoides, Hilaria jamesii, and Muhlenbergia porteri were detected in smaller amounts (Appendices A and B). Although perennial grasses generally are higher in fiber and lower in most important nutrients than other types of forage, they generally are more persistent and available during drought than some other forage (McArthur et al., 1994). Therefore, including perennial grasses during reclamation may provide a food source for periods when annual plants are not available. Cacti should also be considered during reclamation for the same reasons.

Most reclamation efforts at Yucca Mountain to date have been directed toward establishing perennial shrubs since shrubs comprise $>80 \%$ of the plant cover at Yucca Mountain (Angerer et al., 1994). Although shrubs made up a relatively small part of the diet of desert tortoises, some species, such as Krameria parvifolia, Ceratoides lanata, and Atriplex confertifolia, were eaten (Appendices A and $B$ ). These shrubs generally are high in nutrients such as nitrogen, sodium, and fat, and may be available to tortoises at times of the year or during drought years when other, preferred species are not available (McArthur et al., 1994). In addition to providing a potential food source for tortoises, shrubs provide cover sites for tortoises, enhance dissemination of other seeds by providing cover for rodents and roosting sites for birds, and provide a microclimate suitable for the germination and growth of annual plants that are difficult to plant or grow on reclaimed sites. Therefore, it is very important to continue promoting the establishment of a mix of shrub species in reclaimed areas similar to that found in adjacent undisturbed areas.

In addition to identifying and incorporating the proper mix of plants, at least two other aspects of reclamation, soil recontouring and decompacting, are important for improving disturbed areas as tortoise habitat. Soil or substrate was removed or added to many disturbed sites at Yucca Mountain, 
creating steep cut and fill slopes. These steep slopes may be susceptible to erosion and restrict access by tortoises. Therefore, when possible, disturbed sites should be recontoured to reduce erosion and provide tortoises access to the vegetation established there. Construction activities also have caused severe soil compaction on many sites. This prevents water infiltration (Iverson et al., 1981) and impedes establishment of plants (Webb and Wilshire, 1980), especially seedlings (Vollmer et al., 1976). Soil compaction also may prevent tortoises from excavating burrows. Therefore soil compaction should be reduced during reclamation. Without these efforts tortoises may not use previously disturbed sites, no matter how much suitable forage is available.

\subsection{MANAGEMENT RECOMMENDATIONS}

The following recommendations should be considered during the reclamation planning stages to promote the growth of palatable forage and develop other habitat features important to tortoises.

- Native annual and perennial forbs eaten by desert tortoises at Yucca Mountain should be included in reclamation seed mixes. Species commonly eaten that should be included when feasible are Astragalus spp., Calochortus flexuosus, Euphorbia albomarginata, Lotus humistratus, Lupimus spp., Mentzelia obscura, and Sphaeralcea ambigua. Other native forbs eaten by tortoises (Appendices A and B) also should be considered.

- Cacti; perennial grasses such as Stipa speciosa, Oryzopsis hymenoides, Hilaria jamesii, and Muhlenbergia porteri; and shrubs occasionally eaten by tortoises (e.g., Krameria parvifolia, Ceratoides lanata, and Atriplex confertifolia) also should be included during reclamation because these plants may be important sources of nutrients when annuals are not available.

- Species such as Amsinckia tessellata, Eriogonum inflatum, Gilia spp., and Stephanomeria panciflora that were eaten by tortoises but naturally invade disturbed areas may, but do not necessarily need to be, seeded in reclaimed areas.

- Non-native species should not be planted on reclaimed sites.

- A mix of shrub species similar to that found in surrounding, undisturbed sites should be promoted during reclamation to enhance establishment of other plants and provide shelter sites for tortoises.

- When necessary, disturbed sites should be recontoured and soil compaction reduced prior to revegetation to improve these areas as tortoise habitat. 


\section{REFERENCES}

Angerer, J. P., W. K. Ostler, W. D. Gabbert, and B. W. Schultz. 1994. Secondary succession on disturbed sites at Yucca Mountain, Nevada. U.S. Department of Energy Topical Report EGG $11265-1118.73 \mathrm{pp}$.

Beatley, J. C. 1974. Phenological events and their environmental triggers in Mojave Desert ecosystems. Ecology 55:856-863.

Beatley, J. C. 1976. Vascular plants of the Nevada Test Site and Central-Southern Nevada: ecological and geographic distributions. National Technical Information Service, Office of Technical Information, Energy Research and Development Administration. Springfield, VA. TID-26881. $308 \mathrm{pp}$.

Burge, B. L, and W. G. Bradley. 1976. Population density, structure and feeding habits of the desert tortoise, Gopherus agassizi, in a low desert study area in southern Nevada. Proceedings of the Desert Tortoise Council Symposium 1976:51-74.

D'Antonio, C. M., and P. M. Vitousek. 1992. Biological invasions by exotic grasses, the grass/fire cycle, and global change. Annual Review of Ecology and Systematics 23:63-87.

DOE (U.S. Department of Energy). 1988. Site Characterization Plan, Yucca Mountain Site, Nevada Research and Development Area, Nevada. U.S. Department of Energy, Nevada Nuclear Waste Storage Investigations Project Document, Las Vegas, Nevada, DOE/RW-0199.

DOE (U.S. Department of Energy). 1989a. Biological assessment of the effects of Site Characterization Activities on the endangered desert tortoise. U.S. Department of Energy, Yucca Mountain Project Office, Las Vegas, Nevada.

DOE (U.S. Department of Energy). 1989b. Draft reclamation program plan for site characterization: Yucca Mountain Project. Office of Civilian Radioactive Waste Management, Washington DC. DOE/RW-0244. $32 \mathrm{pp}$.

EG\&G (EG\&G Energy Measurements, Inc). 1994. Yucca Mountain biological resources monitoring program annual report, October 1992-December 1993. EG\&G/EM Santa Barbara Operations, EGG 11265-1073. 69pp.

Esque, T. A. 1994. Diet and diet selection of the desert tortoise (Gopherus agassizii) in the northeastern Mojave Desert. M.S. Thesis, Colorado State University, Fort Collins. 243 pp.

Hansen, R. M., M. K. Johnson, and T. R. Van Devender. 1976. Foods of the desert tortoise, Gopherus agassizii, in Arizona and Utah. Herpetologica 32:247-251.

Henen, B. T. 1994. Seasonal and annual energy and water budgets of female desert tortoises (Xerobates agassizii) at Goffs, California. Ph.D. Dissertation, University of California, Los Angeles. $185 \mathrm{pp}$. 
Hughes, A. L., D. W. Brickey, and K. K. Zander. In prep. Habitat disturbances associated with the Yucca Mountain Site Characterization Project June 21, 1991- June 30, 1995. U. S. Department of Energy Topical Report EGG-11265-1168. 7 pp.

Iverson, R. M., B. S. Hinkley, and R. M. Webb. 1981. Physical effects of vehicular disturbances on arid landscapes. Science 212:915-917.

Jarchow, J. L. 1984. Veterinary management of the desert tortoise, Gopherus agassizii, at the Arizona-Sonora Desert Museum: a rational approach to diet. Proceedings of the Desert Tortoise Council Symposium 1984:83-94.

Jennings, W. B. 1993. Foraging ecology of the desert tortoise (Gopherus agassizii) in the western Mojave Desert. M.S. Thesis, University of Texas, Arlington. 89 pp.

McArthur, E. D., S. C. Sanderson, and B. L. Webb. 1994. Nutritive quality and mineral content of potential desert tortoise food plants. U.S. Forest Service Research Paper INT-473. 26 pp.

Medica, P. A., C. L. Lyons, and F. B. Turner. 1982. A comparison of 1981 populations of desert tortoises (Gopherus agassizi) in grazed and ungrazed areas in Ivanpah Valley, California. Proceedings of the Desert Tortoise Council Symposium 1982:99-124.

Morgart, J. R., P. R. Krausman, W. H. Brown, and F. M. Whiting. 1986. Chemical analysis of mountain sheep forage in the Virgin Mountains, Arizona. University of Arizona, College of Agriculture, Technical Bulletin 257. $11 \mathrm{pp}$.

Nagy, K. A., and P. A. Medica. 1986. Physiological ecology of desert tortoises in southern Nevada. Herpetologica 42:73-92.

National Ecology Research Center. 1990. Assessment of biological information for listing the desert tortoise as an endangered species in the Mojave Desert: predecision document. U. S. Fish and Wildlife Service, Portland, Oregon. 104 pp.

O'Farrell, T. P., and E. Collins. 1984. 1983 biotic studies of Yucca Mountain, Nevada Test Site, Nye County, Nevada. U.S. Department of Energy Topical Report EGG-10282-2031.

Rautenstrauch, K. R, P. R. Krausman, F. M. Whiting, and W. H. Brown. 1988. Nutritional quality of desert mule deer forage in King Valley, Arizona. Desert Plants 8:172-174.

Rautenstrauch, K. R., M. K. Cox, T. B. Doerr, R. A. Green, J. M. Mueller, T. P. O'Farrell, D. L. Rakestraw. 1991. Management and research of desert tortoises for the Yucca Mountain Project. Proceedings of the International High-Level Radioactive Waste Management Conference 2:14491455.

Snider, J. R. 1992. Foraging ecology and sheltersite characteristics of Sonoran Desert tortoises. Proceedings of the Desert Tortoise Council Symposium 1992:82-94. 
Sparks, D. R., and J. C. Malechek. 1968. Estimating percentage dry weight in diets using a microscopic technique. Journal of Range Management 21:264-265.

Turner, F. B., P. A. Medica, and C. L. Lyons. 1984. Reproduction and survival of the desert tortoise (Scaptochelys agassizii) in Ivanpah Valley, California. Copeia 1984:811-820.

U.S. Fish and Wildlife Service. 1990. Letter from FWS to C. Gertz, Yucca Mountain Project Manager, containing the Biological Opinion and Incidental Take Provisions for Site Characterization Activities of the Yucca Mountain Project. February 9, 1990.

U.S. Fish and Wildlife Service. 1994. Desert Tortoise (Mojave Population) Recovery Plan. U.S. Fish and Wildlife Service, Portland, Oregon. 73 pp., plus appendices.

Vollmer, A. T., B. G. Maza, P. A. Medica, F. B. Turner, and S. A. Bamberg. 1976. The impact of off-road vehicles on a desert ecosystem. Environmental Management 2:115-129.

Webb, R. H., and H. B. Wilshire. 1980. Recovery of soils and vegetation in a Mojave desert ghost town, Nevada, U.S.A. Journal of Arid Environments 3:291-303.

Woodbury, A. M., and R. Hardy. 1948. Studies of the desert tortoise, Gopherus agassizii. Ecological Monographs 18:145-200. 


\section{APPENDIX A}

Percent composition and percent frequency of occurrence of forage species identified during feeding observations of desert tortoises at Yucca Mountain, Nevada, during 1993, 1994, and 1995. 


\section{APPENDIX A1}

Percent composition and percent frequency of occurrence of forage species in 6,298 bites during 100 foraging observations of 55 desert tortoises at Yucca Mountain, Nevada, during 1993.

\begin{tabular}{|c|c|c|}
\hline Species $^{1}$ & $\%$ Composition & $\%$ Frequency of Occurrence \\
\hline Lotus humistratus ${ }^{\mathrm{N}, \mathrm{A}, \mathrm{F}}$ & 46.8 & 52.0 \\
\hline Bromus rubens ${ }^{\mathrm{E}, \mathrm{A}, \mathrm{G}}$ & 12.8 & 40.0 \\
\hline Amsinckia tessellata ${ }^{\mathrm{N}, \mathrm{A}, \mathrm{F}}$ & 6.6 & 14.0 \\
\hline Mentzelia obscura ${ }^{\mathrm{N}, \mathrm{A}, \mathrm{F}}$ & 6.2 & 1.0 \\
\hline Sphaeralcea ambigua ${ }^{\mathrm{N}, \mathrm{P}, \mathrm{F}}$ & 5.7 & 11.0 \\
\hline Stephanomeria spp. ${ }^{\mathrm{N}, \mathrm{P}, \mathrm{F}}$ & 5.7 & 1.0 \\
\hline Erodium cicutarium $\mathrm{E}, \mathrm{A}, \mathrm{F}$ & 2.9 & 3.0 \\
\hline Lupinus flovoculatus ${ }^{\mathrm{N}, \mathrm{A}, \mathrm{F}}$ & 2.2 & 2.0 \\
\hline Calochortus flexuosus ${ }^{\mathrm{N}, \mathrm{P}, \mathrm{F}}$ & 1.6 & 5.0 \\
\hline Cryptantha circumscissa ${ }^{\mathrm{N}, \mathrm{A}, \mathrm{F}}$ & 1.0 & 1.0 \\
\hline Lupinus spp. ${ }^{\mathrm{N}, \mathrm{A}, \mathrm{F}}$ & 1.0 & 3.0 \\
\hline Stipa speciosa ${ }^{\mathrm{N}, \mathrm{P}, \mathrm{G}}$ & 1.0 & 2.0 \\
\hline Erioneuron pulchellum $\mathrm{N,P,G}$ & 0.9 & 3.0 \\
\hline Cryptantha nevadensis ${ }^{\mathrm{N}, \mathrm{A}, \mathrm{F}}$ & 0.7 & 1.0 \\
\hline Dichelostemma pulchellum ${ }^{\mathrm{N}, \mathrm{P}, \mathrm{F}}$ & 0.6 & 3.0 \\
\hline Phacelia spp. ${ }^{\mathrm{N}, \mathrm{A}, \mathrm{F}}$ & 0.5 & 1.0 \\
\hline Gilia spp. ${ }^{\mathrm{N}, \mathrm{A}, \mathrm{F}}$ & 0.5 & 3.0 \\
\hline Euphorbia albomarginata ${ }^{N, P, F}$ & 0.4 & 1.0 \\
\hline Cryptantha spp. $\mathrm{N}, \mathrm{A}, \mathrm{F}$ & 0.4 & 3.0 \\
\hline Eriogomum inflatum $\mathrm{N}, \mathrm{P}, \mathrm{F}$ & 0.3 & 3.0 \\
\hline Langloisia schottii ${ }^{\mathrm{N}, \mathrm{A}, \mathrm{F}}$ & 0.3 & 1.0 \\
\hline Cryptantha pterocarya ${ }^{\mathrm{N}, \mathrm{A}, \mathrm{F}}$ & 0.2 & 2.0 \\
\hline Oxytheca perfoliata ${ }^{\mathrm{N}, \mathrm{A}, \mathrm{F}}$ & 0.2 & 1.0 \\
\hline Eschscholzia minutiflora ${ }^{\mathrm{N}, \mathrm{A}, \mathrm{F}}$ & 0.1 & 1.0 \\
\hline Lupinus concinmus $\mathrm{N}, \mathrm{A}, \mathrm{F}$ & 0.1 & 1.0 \\
\hline Lagomorph scat $^{\circ}$ & 0.1 & 1.0 \\
\hline Pectocarya platycarpa ${ }^{\mathrm{N}, \mathrm{A}, \mathrm{F}}$ & 0.1 & 1.0 \\
\hline Lichen $^{\circ}$ & $<0.1$ & 1.0 \\
\hline Vulpia octoflora ${ }^{\mathrm{N}, \mathrm{A}, \mathrm{G}}$ & $<0.1$ & 1.0 \\
\hline Hymenoclea salsola $\mathrm{N,P,S}$ & $<0.1$ & 1.0 \\
\hline Unknown $^{\circ}$ & 0.9 & 3.0 \\
\hline
\end{tabular}

${ }^{1} \mathrm{~N}=$ Native, $\mathrm{E}=$ Exotic, $\mathrm{A}=$ Annual, $\mathrm{P}=$ Perennial, $\mathrm{F}=$ Forb, $\mathrm{G}=\mathrm{Grass}, \mathrm{S}=$ Shrub, $\mathrm{O}=$ Other 


\section{APPENDIX A2}

Percent composition and percent frequency of occurrence of forage species in 4,324 bites during 89 foraging observations of 61 desert tortoises at Yucca Mountain, Nevada, during 1994.

\begin{tabular}{|c|c|c|}
\hline Species $^{1}$ & $\%$ Composition & $\%$ Frequency of Occurrence \\
\hline Bromus rubens $\mathrm{EA,G}$ & 46.1 & 67.4 \\
\hline Lotus humistratus N,A,F & 17.0 & 23.6 \\
\hline Sphaeralcea ambigua ${ }^{\mathrm{N}, P, F}$ & 11.8 & 7.9 \\
\hline Amsinckia tessellata $\mathrm{N,A,F}$ & 4.5 & 13.5 \\
\hline Stephanomeria parryi $\mathrm{N}, \mathrm{P}, \mathrm{F}$ & 4.3 & 2.2 \\
\hline Erioneuron pulchellum ${ }^{\text {N,P.G }}$ & 4.1 & 3.4 \\
\hline Erodium cicutarium ${ }^{\mathrm{B}, \mathrm{A}, \mathrm{F}}$ & 3.8 & 10.1 \\
\hline Euphorbia albomarginata $\mathrm{N,P,F}$ & 2.2 & 1.1 \\
\hline Eriogomum inflatum ${ }^{\mathrm{N}, \mathrm{P}, \mathrm{F}}$ & 1.7 & 2.2 \\
\hline Pectocarya platycarpa ${ }^{\mathrm{N}, \mathrm{A}, \mathrm{F}}$ & 1.4 & 1.1 \\
\hline Leptodactylon pungens ${ }^{\mathrm{N}, \mathrm{P}, \mathrm{S}}$ & 0.8 & 1.1 \\
\hline Stipa speciosa ${ }^{\mathrm{N}, \mathrm{P}, \mathrm{G}}$ & 0.7 & 1.1 \\
\hline Bromus tectorum $\mathrm{B}, \mathrm{A}, \mathrm{G}$ & 0.4 & 1.1 \\
\hline Atriplex confertifolia ${ }^{\mathrm{N}, \mathrm{P}, \mathrm{S}}$ & 0.2 & 1.1 \\
\hline Astragalus spp. ${ }^{\mathrm{N}, \mathrm{A}, \mathrm{P}, \mathrm{F}}$ & 0.2 & 1.1 \\
\hline Astragalus layneae ${ }^{\mathrm{N}, \mathrm{P}, \mathrm{F}}$ & 0.1 & 1.1 \\
\hline Grayia spinosa ${ }^{\mathrm{N}, \mathrm{P}, \mathrm{S}}$ & $<0.1$ & 1.1 \\
\hline Krameria parvifolia ${ }^{\mathrm{N}, \mathrm{P}, \mathrm{S}}$ & $<0.1$ & 1.1 \\
\hline Unknown $^{0}$ & 0.6 & 3.4 \\
\hline
\end{tabular}

${ }^{1} \mathrm{~N}=$ Native, $\mathrm{E}=$ Exotic, $\mathrm{A}=$ Annual, $\mathrm{P}=$ Perennial, $\mathrm{F}=$ Forb, $\mathrm{G}=\mathrm{Grass}, \mathrm{S}=$ Shrub, $\mathrm{O}=$ Other 


\section{APPENDIX A3}

Percent composition and percent frequency of occurrence of forage species in 3,374 bites during 58 foraging observations of 45 desert tortoises at Yucca Mountain, Nevada, during 1995.

\begin{tabular}{|c|c|c|}
\hline Species $^{1}$ & $\%$ Composition & $\%$ Frequency of Occurrence \\
\hline Lotus humistratus $\mathrm{N,A,F}$ & 34.8 & 48.3 \\
\hline Sphaeralcea ambigua ${ }^{\mathrm{N}, \mathrm{P}, \mathrm{F}}$ & 17.9 & 12.1 \\
\hline Astragalus spp. ${ }^{\mathrm{N}, \mathrm{A}, \mathrm{P}, \mathrm{F}}$ & 8.8 & 8.6 \\
\hline Erodium cicutarium ${ }^{\mathrm{E}, \mathrm{A}, \mathrm{F}}$ & 8.8 & 3.4 \\
\hline Bromus rubens E,A,G & 4.3 & 24.1 \\
\hline Lupinus spp. ${ }^{N, A, F}$ & 4.0 & 5.2 \\
\hline Camissonia boothii ${ }^{\mathrm{N}, \mathrm{A}, \mathrm{F}}$ & 3.5 & 1.7 \\
\hline Gilia spp. ${ }^{\mathrm{N}, \mathrm{A}, \mathrm{F}}$ & 3.0 & 5.2 \\
\hline Chorizanthe thurberi ${ }^{\mathrm{N}, \mathrm{A}, \mathrm{F}}$ & 2.2 & 1.7 \\
\hline Lupinus concinnus $\mathrm{N}, \mathrm{A}, \mathrm{F}$ & 2.0 & 5.2 \\
\hline Krameria parvifolia ${ }^{\mathrm{N}, \mathrm{P}, \mathrm{S}}$ & 1.1 & 1.7 \\
\hline Cactus N,P,C & 1.0 & 1.7 \\
\hline Pectocarya platycarpa ${ }^{\mathrm{N}, \mathrm{A}, \mathrm{F}}$ & 1.0 & 5.2 \\
\hline Amsinckia tessellata ${ }^{\mathrm{N}, \mathrm{A}, \mathrm{F}}$ & 0.9 & 5.2 \\
\hline Calochortus flexuosus ${ }^{\mathrm{N}, \mathrm{P}, \mathrm{F}}$ & 0.7 & 1.7 \\
\hline Cryptantha spp. ${ }^{\mathrm{N}, \mathrm{A}, \mathrm{F}}$ & 0.3 & 1.7 \\
\hline Chorizanthe brevicormu $\mathrm{N,A,F}$ & 0.2 & 1.7 \\
\hline Cryptantha micrantha ${ }^{\mathrm{N}, \mathrm{A}, \mathrm{F}}$ & 0.2 & 1.7 \\
\hline Pectocarya setosa ${ }^{\mathrm{N}, \mathrm{A}, \mathrm{F}}$ & 0.2 & 1.7 \\
\hline Stephanomeria parryi ${ }^{\mathrm{N}, \mathrm{P}, \mathrm{F}}$ & 0.2 & 1.7 \\
\hline Stephanomeria pauciflora ${ }^{\mathrm{N}, \mathrm{P}, \mathrm{F}}$ & 0.1 & 1.7 \\
\hline Oryzopsis hymenoides $\mathrm{N}, \mathrm{P}, \mathrm{G}$ & 0.1 & 1.7 \\
\hline Unknown $^{\circ}$ & 4.7 & 3.4 \\
\hline
\end{tabular}

${ }^{1} \mathrm{~N}=$ Native, $\mathrm{E}=$ Exotic, $\mathrm{A}=$ Annual, $\mathrm{P}=$ Perennial, $\mathrm{F}=\mathrm{Forb}, \mathrm{G}=\mathrm{Grass}, \mathrm{S}=$ Shrub $, \mathrm{C}=\mathrm{Cactus}, \mathrm{O}=$ Other 


\section{APPENDIX B}

Percent composition and percent frequency of occurrence of forage items in desert tortoise scat collected at Yucca Mountain, Nevada, during 1992 and 1993. 


\section{APPENDIX B1}

Percent composition and percent frequency of occurrence of forage items in 88 scat collected at Yucca Mountain, Nevada, during 1992.

\begin{tabular}{|c|c|c|}
\hline Forage Group ${ }^{1}$ & $\%$ Composition ${ }^{2}$ & $\%$ Frequency of Occurrence \\
\hline Sphaeralcea ambigua ${ }^{\mathrm{N}, \mathrm{P}, \mathrm{F}}$ & 25.8 & 75.0 \\
\hline Lotus spp. - Lupinus spp. ${ }^{\mathrm{N}, \mathrm{A}, \mathrm{F}}$ & 15.4 & 51.1 \\
\hline Bromus rubens $\mathrm{B}, \mathrm{A}, \mathrm{G}$ & 14.5 & 78.4 \\
\hline Schismus arabicus ${ }^{\mathrm{E}, \mathrm{A}, \mathrm{G}}$ & 7.0 & 35.2 \\
\hline Boraginaceae $\mathrm{N}^{\mathrm{N}, \mathrm{A}, \mathrm{P}, \mathrm{F}}$ & 3.1 & 31.8 \\
\hline Arthropods ${ }^{\circ}$ & 2.7 & 33.0 \\
\hline Sporobolus cryptandrus ${ }^{\text {N,P,G }}$ & 2.3 & 21.6 \\
\hline Erodium cicutarium $\mathrm{E}, \mathrm{A}, \mathrm{F}$ & 2.0 & 28.4 \\
\hline Mentzelia obscura ${ }^{\mathrm{N}, \mathrm{A}, \mathrm{F}}$ & 1.7 & 29.6 \\
\hline Hilaria jamesii ${ }^{\mathrm{N}, \mathrm{P}, \mathrm{G}}$ & 1.4 & 6.8 \\
\hline Cactus ${ }^{N}, P, C$ & 1.4 & 23.9 \\
\hline Leptodactylon pungens ${ }^{\mathrm{N}, \mathrm{P}, \mathrm{S}}$ & 0.8 & 2.4 \\
\hline Oenothera spp. $\mathrm{N}, \mathrm{A}, \mathrm{P}, \mathrm{F}$ & 0.8 & 11.4 \\
\hline Ceratoides lanata ${ }^{\mathrm{N}, \mathrm{P}, \mathrm{S}}$ & 0.8 & 25.0 \\
\hline Aristida spp. ${ }^{\mathrm{N}, \mathrm{P}, \mathrm{G}}$ & 0.7 & 9.1 \\
\hline Legumes ${ }^{\mathrm{N}, \mathrm{P}, \mathrm{A}, \mathrm{S}, \mathrm{F}}$ & 0.5 & 19.3 \\
\hline Krameria parvifolia ${ }^{\mathrm{N}, P, S}$ & 0.5 & 4.6 \\
\hline Larrea tridentata ${ }^{\mathrm{N}, \mathrm{P}, \mathrm{S}}$ & 0.5 & 5.7 \\
\hline Muhlenbergia porteri ${ }^{\mathrm{N}, \mathrm{P}, \mathrm{G}}$ & 0.5 & 3.4 \\
\hline Polemoniaceae ${ }^{N, A, P, F}$ & 0.4 & 5.7 \\
\hline Stipa speciosa ${ }^{\mathrm{N}, \mathrm{P}, \mathrm{G}}$ & 0.4 & 17.1 \\
\hline Unknown Composites ${ }^{\text {N,A,P,F,S }}$ & 0.3 & 11.4 \\
\hline Hair $^{\circ}$ & 0.3 & 2.3 \\
\hline Malvaceae ${ }^{N, A, P, S, F}$ & 0.2 & 10.2 \\
\hline Liliaceae $\mathrm{N}^{\mathrm{N}, \mathrm{P}, \mathrm{F}}$ & 0.2 & 2.3 \\
\hline Poa spp. ${ }^{\mathrm{N}, \mathrm{P}, \mathrm{G}}$ & 0.1 & 3.4 \\
\hline Vulpia octoflora ${ }^{\mathrm{N}, \mathrm{P}, \mathrm{G}}$ & 0.1 & 3.4 \\
\hline Cirsium spp. N,A,P,F & 0.1 & 3.4 \\
\hline Artemisia tridentata ${ }^{\mathrm{N}, \mathrm{P}, \mathrm{S}}$ & 0.1 & 5.7 \\
\hline Ephedra spp. N,P,s & $<0.1$ & 2.3 \\
\hline Atriplex spp. ${ }^{\mathrm{N}, \mathrm{P}, \mathrm{S}}$ & $<0.1$ & 3.4 \\
\hline Bone $^{\circ}$ & $<0.1$ & 1.1 \\
\hline Eriogomum spp. ${ }^{\mathrm{N}, \mathrm{P}, \mathrm{s}}$ & $<0.1$ & 1.1 \\
\hline Dalea spp. ${ }^{\mathrm{N}, \mathrm{P}, \mathrm{F}}$ & $<0.1$ & 1.1 \\
\hline Argemone spp. ${ }^{\mathrm{N}, \mathrm{P}, \mathrm{F}}$ & $<0.1$ & 1.1 \\
\hline
\end{tabular}


APPENDLX B1, continued

Forage Group ${ }^{1}$ \%Composition ${ }^{2}$

$\%$ Frequency of Occurrence

Astragalus spp. ${ }^{\mathrm{N}, \mathrm{A}, \mathrm{P}, \mathrm{F}, \mathrm{S}}$

$<0.1$

1.1

Pollen ${ }^{\circ}$

$<0.1$

1.1

Sitanion spp. ${ }^{\mathrm{N}, \mathrm{P}, \mathrm{G}}$

$<0.1$

1.1

Fungus ${ }^{\circ}$

$<0.1$

1.1

$<0.1$

1.1

Unknown vegetation ${ }^{\circ}$

8.9

80.7

${ }^{1} \mathrm{~N}=$ Native, $\mathrm{E}=$ Exotic, $\mathrm{A}=$ Annual, $\mathrm{P}=$ Perennial, $\mathrm{F}=$ Forb, $\mathrm{G}=\mathrm{Grass}, \mathrm{S}=$ Shrub, $\mathrm{C}=$ Cactus, $\mathrm{O}=$ Other

${ }^{2}$ Percent composition is an average of percentages; therefore, the sum of percent compositions for all forage groups may not total $100 \%$. 


\section{APPENDIX B2}

Percent composition and frequency of occurrence of forage species in 88 desert tortoise scat collected at Yucca Mountain, Nevada, during 1993.

\begin{tabular}{|c|c|c|}
\hline Forage Group ${ }^{1}$ & $\%$ Composition $^{2}$ & $\%$ Frequency of Occurrence \\
\hline Lotus spp. - Lupinus spp. ${ }^{\mathrm{N}, \mathrm{A}, \mathrm{F}}$ & 31.6 & 58.0 \\
\hline Sphaeralcea ambigua ${ }^{\mathrm{N}, \mathrm{P}, \mathrm{F}}$ & 18.5 & 58.0 \\
\hline Boraginaceae ${ }^{N, A, P, \bar{F}}$ & 12.7 & 75.0 \\
\hline Erodium cicutorium ${ }^{\mathrm{E}, \mathrm{A}} \mathrm{F}$ & 3.8 & 31.8 \\
\hline Bromus rubens ${ }^{\mathrm{B}, \mathrm{A}, \mathrm{G}}$ & 2.0 & 42.1 \\
\hline Sporobolus cryptandrus ${ }^{N, P, G}$ & 1.6 & 15.9 \\
\hline Polemoniaceae ${ }^{\mathrm{N}, \mathrm{A}, \mathrm{P}, \mathrm{F}}$ & 1.3 & 3.4 \\
\hline Arthropod ${ }^{\circ}$ & 1.1 & 19.3 \\
\hline Cactus ${ }^{N, P, C}$ & 1.0 & 13.6 \\
\hline Legume $^{\mathrm{N}, \mathrm{A}, \mathrm{P}, \mathrm{S}, \mathrm{F}}$ & 1.0 & 31.8 \\
\hline Hilaria jamesii $\mathrm{N}, \mathrm{P}, \mathrm{G}$ & 0.5 & 3.4 \\
\hline Stipa speciosa ${ }^{\mathrm{N}, \mathrm{P}, \mathrm{G}}$ & 0.4 & 5.7 \\
\hline Brassicaceae ${ }^{\mathrm{N}, \mathrm{A}, \mathrm{P}, \mathrm{F}, \mathrm{S}}$ & 0.4 & 9.1 \\
\hline Sitanion spp. ${ }^{\mathrm{N}, \mathrm{P}, \mathrm{G}}$ & 0.3 & 11.4 \\
\hline Mentzelia obscura ${ }^{\mathrm{N}, \mathrm{A}, \mathrm{F}}$ & 0.2 & 10.2 \\
\hline Erioneuron pulchellum ${ }^{\mathrm{N}, \mathrm{P}, \mathrm{G}}$ & 0.2 & 8.0 \\
\hline Atriplex spp. ${ }^{\mathrm{N}, \mathrm{P}, \mathrm{S}}$ & 0.2 & 6.8 \\
\hline Krameria parvifolia ${ }^{\mathrm{N}, \mathrm{P}, \mathrm{S}}$ & 0.1 & 6.8 \\
\hline Larrea tridentata ${ }^{\mathrm{N}, \mathrm{P}, \mathrm{S}}$ & 0.1 & 4.6 \\
\hline Schismus arabicus ${ }^{\mathrm{E}, \mathrm{A}, \mathrm{G}}$ & 0.1 & 6.8 \\
\hline Ceratoides lanata ${ }^{\mathrm{N}, \mathrm{P}, \mathrm{S}}$ & 0.1 & 4.6 \\
\hline Oenothera spp. ${ }^{\mathrm{N}, \mathrm{A}, \mathrm{P}, \mathrm{F}}$ & 0.1 & 1.1 \\
\hline Descurainia spp. $\mathrm{N}_{\mathrm{N}, \mathrm{F}}$ & $<0.1$ & 2.3 \\
\hline Fungus $^{\circ}$ & $<0.1$ & 1.1 \\
\hline Artemisia tridentata ${ }^{\mathrm{N}, \mathrm{P}, \mathrm{S}}$ & $<0.1$ & 2.3 \\
\hline Bone $^{\circ}$ & $<0.1$ & 1.1 \\
\hline Muhlenbergia porteri ${ }^{\mathrm{N}, \mathrm{P}, \mathrm{G}}$ & $<0.1$ & 1.1 \\
\hline Delphinium spp. & $<0.1$ & 1.1 \\
\hline Eriogonum spp. ${ }^{\mathrm{N}, \mathrm{P}, \mathrm{S}}$ & $<0.1$ & 1.1 \\
\hline Plantago spp. ${ }^{\mathrm{N}, \mathrm{A}, \mathrm{F}}$ & $<0.1$ & 1.1 \\
\hline Ephedra spp. ${ }^{\mathrm{N}, \mathrm{P}, \mathrm{S}}$ & $<0.1$ & 1.1 \\
\hline Unknown Vegetation ${ }^{\circ}$ & 15.9 & 98.9 \\
\hline
\end{tabular}

' $\mathrm{N}=$ Native, $\mathrm{E}=$ Exotic, $\mathrm{A}=$ Annual, $\mathrm{P}=$ Perennial, $\mathrm{F}=$ Forb, $\mathrm{G}=\mathrm{Grass}, \mathrm{S}=$ Shrub, $\mathrm{C}=$ Cactus, $\mathrm{O}=$ Other

2 Percent composition is an average of percentages; therefore, the sum of percent compositions for all forage groups may not total $100 \%$. 